\title{
Museum Discourse: Negotiating The Fragments Rina Kundu
}

\begin{abstract}
A recent report written by the American Association of Museums (1992) directs museums to place education at the center of their commitment to society and to meet the needs of diversity in their audiences. I have seen evidence of this challenge to teach towards diversity in the institution in which I now work. What I have noticed is that the museum's education staff is interested in creating a more inclusive place, where various groups can participate in meaning-making. This position of course is informed by the debate that points to how museums are powerful social instruments for the creation and maintenance of the world in which we live. A number of teaching strategies and issues on art, museums, culture, and difference are discussed at the site in relationship to creating a people-centered environment.
\end{abstract}

I however believe how all of these issues and strategies are intelligible to individual educators including docents needs to be examined. Museum educators attempting to construct meaningful discourse about their practices and about how to practice must begin to consider the consequences of the ways in which knowledge, power, and desire are mutually implicated in each other's formations and deployments. Educators do not passively teach about art but engender individual and collective realities by what they do and say. What educators do or say is constituted by the discourses in which they are positioned. To be able to identify discourses that are privileged and discourses that are silenced within a field of possibility may allow us to create pedagological spaces in which there could be openings for the play of difference, a negotiation of the language codes by which art and the discursive practices surrounding it are understood.

A number of artists have investigated the discursive practices of museums. Although their attention has been limited to the problematics of display, I think a very brief discussion of the work of two of these artists might help to bring my own project into focus. Besides, display and traditional touring are quite related. Bal (1992) describes the relationship: “(T)he space of a museum presupposes a walking tour, an order in which the exhibits and panels are to be viewed and read. Thus it addresses an implied 'focalizer' whose tour is the story of the production of knowledge taken in and taken home." (p. 561)

In 1968, as part of his Musee d'Art Moderne, Departement des Aigles series, the artist Marcel Broodthaers installed a museum in his apartment. At the opening, guests were invited into an installation, consisting of empty picture crates, spotlights, ladders, rooms designated as galleries, and color postcard reproductions of nineteenth-century French paintings. Inscriptions on windows in the apartment read "Musee/Museum." By collapsing the site of production with that of reception, Broodthaers revealed not only the framing devices of museums but also called into question the dehistoricizing effects of museums. As Crimp (1993) notes, "By displaying the products of particular 
histories in a reified historical continuum, the museum fetishizes them,...The museum constructs a cultural history by treating its objects independently both of the material conditions of their own epoch and of those of the present." (p. 204)

In 1992, the exhibition Mining the Museum by the artist Fred Wilson was held at the Maryland Historical Society in Baltimore. Although Baltimore's population is about $80 \%$ African American, very little of their history was displayed within the museum. Wilson used the museum's collection of objects and the standards of museum display such as labeling, lighting, and juxtapositioning, to call attention to how museums interpret events, history, art, and truth. Rejecting history as being self-evident and objective, Wilson revealed how history is mediated by historians-- their values, beliefs, interests, and perspectives. For example, in Metalworks, 1723-1880, Wilson juxtaposed crude slave shackles, which were usually kept hidden in storage, against a display of intricately worked silver serving pieces. Wilson deconstructed how the interpreter of history, in this case, the museum, shaped its account of the past-how an alternative historical account is suppressed in categorization and display (Ward, 1995).

These installations reveal that museums are indeed sites for social practices and are thus constituted by discourses. These works demonstrate how the museum sanitizes our engagement with the past by limiting our contemplation to the aesthetic. Broodthaers demonstrated the dehistoricizing effects of the museum and thus the emergence of the autonomous art object as commodity. Wilson placed an artifact in a context from which it was excluded, thus changing the context and reminding us of the words of Benjamin (1969): "There is no document of civilization which is not at the same time a document of barbarism." (p.257) The discourses in which Broodthaers and Wilson are positioned come into play with those that constitute the museum.

These artists expose how discourses set limits which enable particular practices of signification and constrain others. My own project will also look at the environment of a museum, the discursive practices of a museum, to see how educators stage signification, deploy relations of power through their choices and actions, and construct and embody yalues through their framings. To historicize those discourses (to expose their frames), interrupts their naturalness, leading to implications for what Lather (1991) describes as pedagogical spaces where oppositional knowledges and negotiated meanings can take place. An understanding of teaching strategies used in museums and how they are situated in power-knowledge structures would provide museum educators with new opportunities to critically analyze and question the intelligibility of the museological space and how their choices and practices both enable and inhibit ways of imagining their roles as teaching toward difference. As Cherryholmes (1988) states, "Rethinking may rejuvenate commitment to conventional discourses-practices or it may lead to something quite different. To avail ourselves of possible choices, however, it is necessary to identify and criticize privileged themes in texts and discourses-practices as well as themes that are silenced." (p. 153) 


\section{Theoretical Framework}

The concept of discourse as developed in poststructuralist theory has become central to my investigation as I search to develop a critical understanding of the processes and relations through which museum educators construct and facilitate meaning-making within the museum setting. I have come to realize that a museum is built upon boundaries (privileged ways of seeing things) which embody assumptions about itself, as well as culture, art, and difference. I am also interested in determining if there are disruptions in these boundaries and what these disruptions might look like.

\section{Poststructuralism}

The impact of poststructuralism has varied but it has been most influential in the humanities and the social sciences. It has much in common with postmodernism, such as the decentering of the modernist subject, the rejection of essentialist concepts of human nature, the rejection of unity and closure, and the rejection of transcendental concepts of truth and meaning. It is hard to pin down a definitive understanding of poststructuralism, but one could perhaps think of it as a critique of the assumptions found in structuralism, that language forms a closed, stable system.

Structuralism revealed that language did not reflect reality but produced it. People come into existence through language and are not free to think outside the rules of their language. Meaning is thus a product of shared systems of signification. The term structuralism derives from Ferdinand de Saussure's linguistic studies. He viewed language synchronically as a system of signs where each sign was made up of a signifier and signified. The relationship between the two is a cultural convention and the sign only has an arbitrary relationship to its referent. Each sign derives its meaning in a system of relations--its difference from other signs in the language chain. Structuralism is an attempt to apply this theory of language to other activities, from the study of human relations to objects. A structuralist analysis would consist of isolating the deep structures by which signs are combined into meaning. These structures were thought to be universal and fixed.

Critics since Saussure have theorized language to be much less stable. Whereas Saussure saw a one-to-one correspondence between signifier and signified, the poststructuralist Jacques Derrida (1976) sees the signifier as not directly related to the signified. There is no fixed distinction between the two and thus there is an endless play of signifiers. Meaning, as produced by the process of difference and deferral, becomes unstable. Eagleton (1996) explains further:

Since the meaning of a sign is a matter of what the sign is not, its meaning is always in some sense absent from it too. Meaning, if you like, is scattered or dispersed along the whole chain of signifiers: it cannot be easily nailed down, it is never fully present in any one sign alone, but is rather a kind of constant flickering of presence and absence together...'Cat' may mean a furry four-legged creature, a 
malicious person,....But even when it just means a furry four-legged creature, this meaning will never quite stay the same from context to context: the signified will be altered by the various chains of signifiers in which it is entangled. (p. 111-112)

Such an understanding of language problematizes the structuralist notion of unity and fixed meaning. For example, Foucault (1972) points to the difficulty of even thinking of a book as a fixed unit:

...beyond the title, the first lines, and the last stop, beyond its internal configuration and its autonomous form, it is caught up in a system of references to other books, other texts, other sentences: it is a node within a network...it indicates itself, constructs itself, only on the basis of a complex field of discourse.

So as Barthes (1977) posits, we must move away from thinking of an art product as a work to thinking of it as a text. "It is a shift from seeing the poem or novel [or image] as a closed entity, equipped with definite meaning which it is the critic's task to decipher, to seeing it as irreducibly plural, an endless play of signifiers which can never be finally nailed down to a single centre, essence or meaning." (Eagleton, 1996, p.120) Meaning is caught up in a play of references rather than being definitive. In this sense, language can never be transparent.

Poststructuralist theorists ask critical questions about signifying practices, such as how certain "truths" attain a privileged position in a given time and place. Derrida (1976) describes how we often think of certain concepts as having a metaphysics of presence-- a logocentrism. The metaphysical is any thought system dependent on a transcendental signified, or a foundational truth upon which a whole hierarchy of meanings can be constructed, such as freedom, independence, order...etc. (Eagleton, 1996). Derrida (1976) however demonstrates that transcendental meaning is a fiction, a product of particular systems of thought. For example, he deconstructs one such metaphysics of presence speech, which in Western philosophy is privileged over writing because it is thought to be authentic and unmediated. He establishes that speech is just as mediated as writing and can even be said to be a form of writing. Foundational truths are often defined by what they exclude, in binary opposition to other concepts and they come about in our desire for a center, an anchoring. As Eagleton (1996) remarks:

Sometimes such meanings are seen as the origin of all others, the source from which they flow;...At other times such meanings may be seen not as the origin but as the goal, toward which all other meanings are or should be steadily marching...But any such theory of history or language as a simple linear evolution misses the web-like complexity of signs... (p. 114)

It is within discourse that words as well as other signifiers produce frameworks for understanding. 


\section{Discourse}

Although there have been many definitions of discourse, Barnes and Duncan (1992) describe the concept of discourse as it is used within poststructuralist theory:

It represents a clear break with earlier ahistorical categories of humanism and structuralism such as human nature, timeless meaning or universal rationality. Although structuralism successfully decentres the individual and, in this sense, is clearly a break with humanism (modernism), it is not fully a postmodern project in that it posits transhistorical structures underlying discourses (best seen in LeviStrauss's work). Poststructural discourse theory, however, sees discourse as conventional and historical. It assumes that discourse, and the 'truths' that they construct, vary among cultural groups and among classes, races, gender-based or other groups, whose interests may clash. (p.8)

Discourses condition the meaning of words, which are deployed within a network of power/knowledge configurations, shaping particular assumptions, aims, choices, and practices. Discourses refer to all types of texts and their web-like complexity "constitutes our social and educational worlds." (Cherryholmes, 1988, p. 8) This understanding of discourse is situated within my interaction with the work of poststructuralist Michel Foucault $(1972,1973,1981)$ and his influence on feminist cultural studies ( McNay, 1992; Sawicki, 1991; Weedon, 1997) and education research (Ball, 1990; Cherryholmes, 1988; Giroux, 1988; Spanos, 1993; Usher \& Edwards, 1994). Foucault's work concerns itself with the institutional effects of discourses and their role in the government of the individual subject. He described the historical conditions that made it possible for certain representations of reality to dictate which kinds of statements come up as candidates for truth and what sorts of questions and answers were taken seriously (Sawicki, 1991). He analyzed how particular regimes of truth, formed by discursive practices, work to produce and maintain existing power relations. His investigations included how individuals are constituted and governed through the discursive practices of psychiatry, medicine, and the penal system.

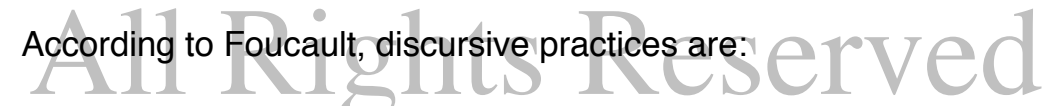
a body of anonymous, historical rules, always determined in the time and space that have defined a given period, and for a given social, economic, geographical, or linguistic area, the conditions of operations of enunciative function. (1972, p.117)

Discourses are "practices that systematically form the objects of which they speak." (Foucault, 1972, p.49) So the object of discourse is constituted by a set of social practices. Discourse is "a system of possibility which makes a field of knowledge possible." (Usher \& Edwards, 1994, p. 90) For example, museum education is not a given but a concept reinvented at different periods for different ends. Discourses however are more than concepts; they constitute 
and operate on subjects. They constitute ways of knowing and being known, through the ordering of particular combinations of narratives, concepts, social practices, and ideologies, as they are relevant to a particular realm of social action ( Barnes \& Duncan, 1992).

Discourses are always part of a wider network of power relations, often most apparent in their material basis in institutional practices, such as the family, the school, the hospital...etc. McNay (1992) explains further:

...the discursive and the material are linked together in a symbiotic relationship. Foucault's most well-known formulation of this symbiosis is the power/knowledge nexus. On the one hand, all knowledge is an effect of a specific regime of power and on the other hand, forms of knowledge constitute the social reality which they describe and analyse...The effects of the power/knowledge complex are relayed through different discourses... (p.27)

Discourses shape the positioning of individuals in an institution, governing who can speak and act with authority, who is silenced, what can be said, and what remains unsaid; therefore, they exclude as well as include. The individual thus becomes the subject of discourse (how one thinks of oneself and acts) and subject to discourse (how one is acted upon and formed) and in the practice of doing so, discourses conceal their own invention (Foucault, 1972). For example, preservice teachers can only speak and think of themselves as educators after they have been subjected to the professional discourses that are in practice at the time. Education "truths" are produced by individuals caught-up and proficient in the discursive practices of their time. Usher \& Edwards (1994) clarify the regulatory power of discourses:

Discourses 'empower' by creating subjects with certain capacities. But these very capacities also 'disempower' by objectifying subjects, making them subject to power. In this process, knowledge is an aspect of regulatory power which operates 'externally'. At the same time, regulation can take the form of self-regulation, where knowledge is self-knowledge. At one level, this produces 'empowered' subjects: individuals who are empowered by learning and knowing more about themselves. However, subjects 'disempower' themselves in the very process of 'self-empowerment', because this very power of learning about oneself is also the condition for self-regulation; one learns the 'limits' of one's own possibilities-- 'limits' which are a function of discourses rather than 'natural' factors. (p. 98)

Discourses are thus constraining as well as enabling; they constitute limits within which ideas and practices are considered to be natural or intelligible.

The structure of discursive practice, however, is not unified but constitute subject positions that are defined in relationship to other discourses. Moreover, a discursive practice can offer more than one subject position and marginalization can create space to resist dominant subject positions. For 
example, Weedon (1997) discusses how feminist discourses lack the social power to realize their versions of knowledge in institutional practices, but they still offer the space to resist dominant subject positions of femininity within those practices. Often contradictions within or among discursive practices work as catalysts for change. Institutions thus become contested sites, where dominant discourses governing the material practices of the institution can be challenged by less dominant discourses, transforming those practices. This would mean as Hooper-Greenhill (1995) has commented that there is no essential identity for museums. The museum's identity is constituted and is subjected " to constant change as the play of dominations shifts and new relations of advantage and disadvantage emerge." (Hooper-Greenhill, 1995, p. 191)

Thus, discourse is a particular perspective from which to view social practice because it takes into account the positions from which people speak, the institutions which prompt them to speak in particular ways, and the mechanisms that distribute what is said (Foucault, 1981). So the museum is subject to discourse as well as a disseminator of discourse. Taking a discursive perspective to the work of the museum teases out how social practices and the people involved in these practices "continuously create and re-create each other." (Cherryholmes, 1988, p. 6)

\section{Methodology}

\section{Paradigmatic Assumptions}

As a researcher interested in postpositivist inquiry, my narrative will be framed by poststructuralist paradigmatic assumptions. A paradigm is a world view which defines the nature of the inquiry, the researcher's place within the research project, and her choice of methods. Derrida (1976) believes that reality is constituted within a social system of signs, such as language. But language is an unstable system because meanings never stay the same from context to context. Because language is filtered through the subjectivities of people and because we can not stand outside of our subjectivities, the distinction between knower and known collapses and truth becomes situated. In such a view, my own knowing is complicated by my own embodiments. As a researcher, I must then be sensitive to the nature of representation and power relations. First, I must acknowledge that my insight into the research site is framed within a network of discourses. The museum itself is also not a stable site but another network of discursive practices and positionings. These layers will meet, intersect, conflict, contradict, move and shift, and thus I must be careful not to subsume the play of difference, taking seriously Scheurich's (1996) insight into how our knowledge/validity projects are about the Same appropriating the Other, and continually asking if it is possible to create, to use Scheurich's (1996) phrase, a "dialogic carnival" (p. 10) in the face of the poststructuralist problematic, the crisis of representation. 


\section{Design of Study}

Since I propose to look at one university museum's educational programming to examine how a network of discursive practices or processes inform educational approaches, I will proceed by conducting:

1. A critical ethnographic study of the site.

2. A research collective at the site.

I will have three groups of data sources. First, I will look at the discourses that educators including myself draw upon to train tour guides. I expect that many of these discourses will be liberal humanist conceptions of art, culture, and difference. Others will be interruptive discourses perhaps from a poststructuralist, neo-marxist, or feminist perspective. Second, I will historicize these discourses, looking at how they relate to a historical field of possibilities. Last, I will then identify the discourses offered by participants as they interact with viewers in the galleries and as they participate in a focus group. I will conduct five focus group meetings where I will encourage collaboration and collective inquiry and where emergent strategies for teaching can be negotiated between guides. My methods will include observations, single person and group interviews, and a discursive analysis of the literature on the history of museum education. My theoretical framings include poststructuralism, feminism, and neo-marxism. Support for my methods come from such museum professionals as Perin (1992), Kuo Wei Tchen (1992), Porter (1996), and Riegel (1996) who have used ethnographic methodologies not only to gain insight on who is learning what in their institutions but also to critique museum practices and Ladson-Billing (1994) and Jones (1992) who discuss reciprocity in the construction of their research tales.

\section{References}

American Association of Museums. (1992). Excellence and equity:

Education and the public dimension of museums. Washington D. C.: Author.

Bal, M. (1992). Telling, showing, showing off. Critical Inquiry, 18 (3), 556-94.

Ball, S. J. (Ed.). (1990). Foucault and education: Disciplines and knowledge. New York: Routledge.

Barnes, T. J. \& Duncan, J. S. (Eds.). (1992). Writing worlds: Discourse, text and metaphor in the representation of landscape. New York: Routledge.

Barthes, R. (1977). Image-music-text (S. Heath, Trans.). New York: Hill \& Wang. 
Benjamin, W. (1969). Illuminations. (H. Zohn, Trans.). New York: Schocker Books.

Cherryholmes, C. (1988). Power and criticism. New York: Teachers College Press.

Crimp, D. (1993). On the museum's ruins. Cambridge, MA: MIT Press

Derrida, J. (1976) Of grammatology (G. C. Spivak, Trans.). Baltimore: The John Hopkins University Press. (Original work published 1967)

Eagleton, T. (1996). Literary theory: An introduction (2nd ed.). Minneapolis, MN: The University of Minnesota Press.

Foucault, M. (1972). The archaeology of knowledge and the discourse on language (A. M. Sheridan Smith, Trans.). New York: Pantheon Books.

Foucault, M. (1973). The order of things: An archaeology of the human sciences (A translation of Les mots et les choses). New York: Vintage Books. (Original work published 1966)

Foucault, M. (1981). The history of sexuality: An introduction. Harmondsworth: Penguin Books.

Giroux, H. (1988). Postmodernism and the discourse of educational criticism. Journal of Education, 179 (3), 5-30.

Hooper-Greenhill, E. (1995). Museums and the shaping of knowledge. New York: Routledge.

Jones, A. (1992). Writing feminist educational research: Am "l" in the text? In S. Middleton \& A. Jones (Eds.), Women and Education in Aotearoa 2 (pp. 18-32). W!o!lington, NZ: Bridget.

Ladson-Billings, (1994). The dreamkeepers: Successful teacher of African American children. San Francisco: Jossey-Bass Publishers

Kuo Wei Tchen, J. (1992). Creating a dialogic museum: The Chinatown History Museum experiment. In I. Karp, C. M. Kreamer, \& S. D. Lavine (Ed.), Museums and communities: The politics of public culture (pp. 285-326). Washington, DC: Smithsonian Institution Press.

Lather, P. (1991). Getting smart: Feminist research and pedagogy with/in the postmodern. New York: Routledge.

McNay, L. (1992). Foucault and feminism: Power, gender and the self. Boston: Northeastern University Press. 
Perin, C. (1992). The communicative circle: Museums as communities. In I. Karp, C. M. Kreamer, \& S. D. Lavine (Eds.), Museums and communities: The Politics of public culture (pp. 1-18). Washington, DC: Smithsonian Institution Press.

Porter, G. (1996). Seeing through solidity: A feminist perspective on museums. In S. MacDonald and G. Fyfe (Eds.), Theorizing museums: Representing identity and diversity in a changing world. Cambridge, MA: Blackwell Publishers.

Riegel, H. (1996). Into the heart of irony: ethnographic exhibitions and the politics of difference. In S. MacDonald and G. Fyfe (Eds.), Theorizing museums: Representing identity and diversity in a changing world. Cambridge, MA: Blackwell Publishers.

Sawicki, J. (1991). Feminism and the power of Foucauldian discourse. In J. Arac (Ed.), After Foucault: Humanistic knowledge, postmodern challenges (pp. 161-78). New Brunswick, NJ: Rutgers University Press.

Scheurich, J. J. (1996). The masks of validity: A deconstructive investigation. Qualitative Studies in Education, 9(1), 1-11.

Spanos, W. V. (1993). The end of education: Toward posthumanism. Minneapolis, MN: University of Minnesota Press.

Usher, R. \& Edwards, R. (1994). Postmodernism and education. New York: Routledge.

Ward, F. (1995). The haunted museum: Institutional critique and publicity. October $73,71-89$.

Weedon, C. (1997). Feminist practice and poststructuralist theory (2nd edition). Cambridge, England: Basil Blackwell.

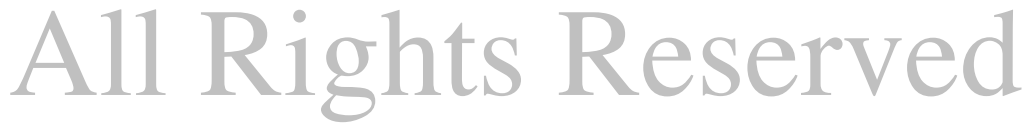

